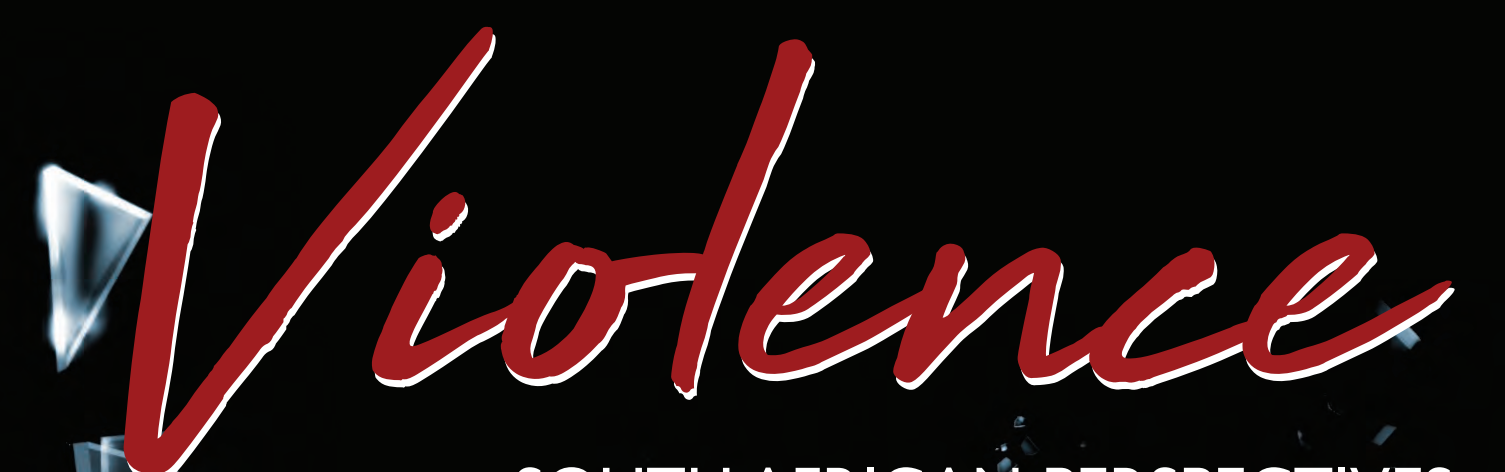

SOUTH,AFRICAN PERSPECTIVES

$\rightarrow$

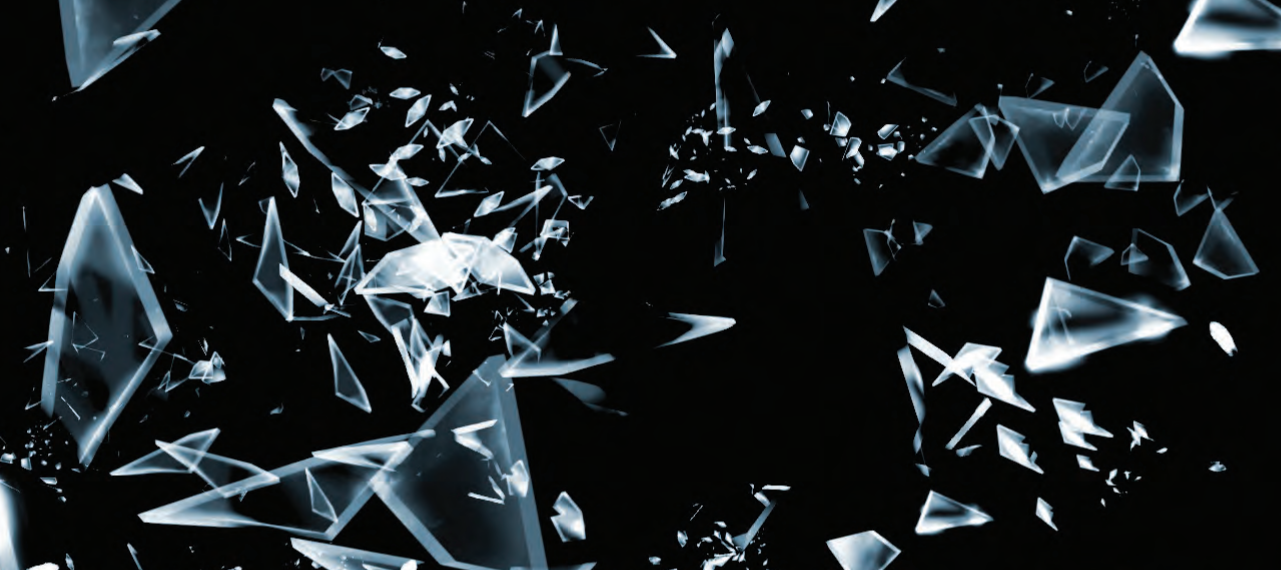

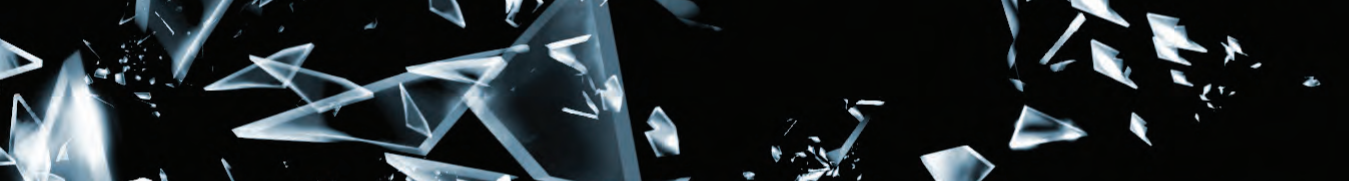

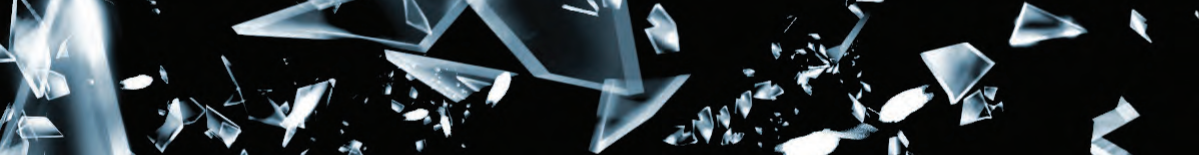

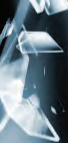

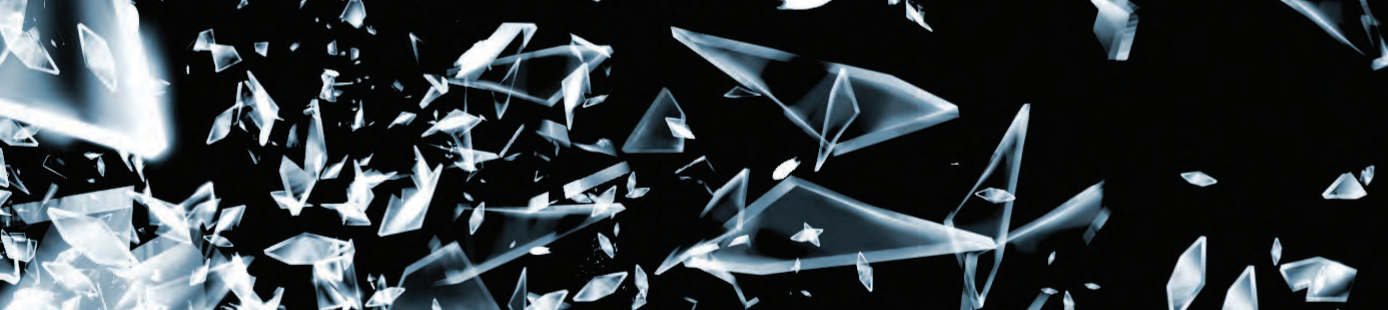

,

a 4 < 6

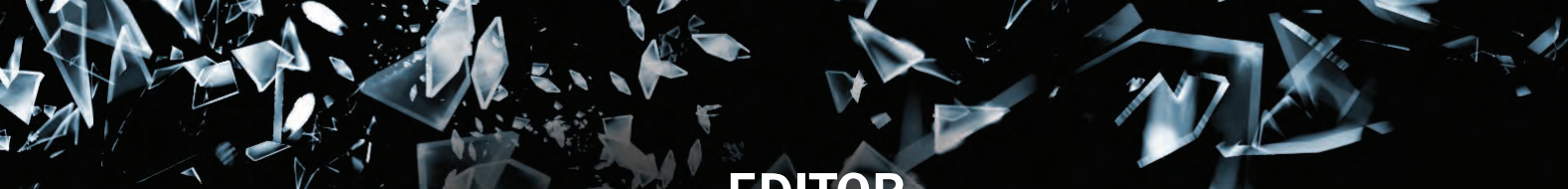

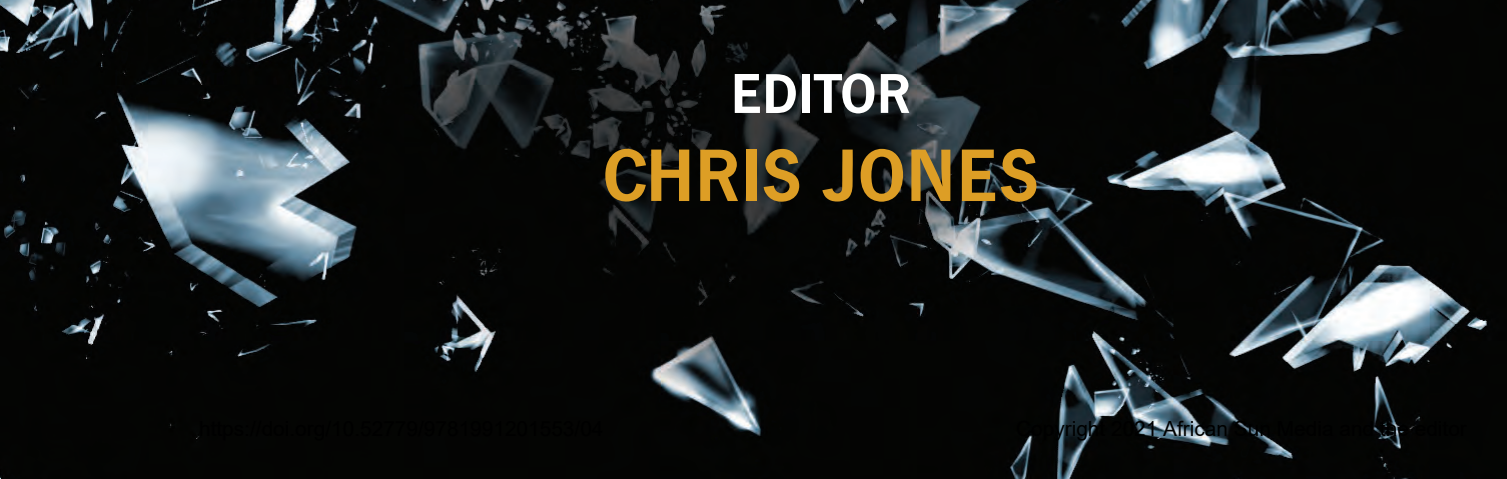




\section{WHO AM I? STORIES OF WOMEN WHO SHIFT BETWEEN IDENTITIES TO EVADE VIOLENCE}

Christina Landman

\section{Keywords}

gender identity; gender violence; shifting identities; submissiveness; women and abuse

\section{INTRODUCTION: AIM AND STRUCTURE}

The chapter will problematise the phenomenon of 'shifting identities' as a preferred way of being within narrative counselling for women facing abuse. In short, it will tell as problem saturated stories, the stories of women who shift continuously from an assertive career identity to a submissive cultural identity to evade violence in private spaces, to mention one example.

This aim is realised by the following definitions, methodological insights, and structure:

1. The notion of 'shifting identities' undermines the discourse that a person has only one 'true' identity. In this chapter, it is presumed that women have a variety of identities, such as a career identity, a religious identity, and a cultural identity. In the Editorial Introduction to a special issue of Feminism \& Psychology, titled 'Shifting Identities Shifting Racisms', Kum-Kum Bhavnani and Ann Phoenix (1994:9) state that identities within one individual are multiple, that they are fluctuating, and that in unequal power relationships they can be in conflict with one another, forcing the individual to shift between them:

[T] he notion of identity as a static and unitary trait which lies within human beings, rather than as an interactional and contextual feature of all social relationships, has been laid to rest. Identity as a dynamic aspect of social relationships, is forged and reproduced through the agency/structure dyad, and is inscribed within unequal power relationships. In other words, identity is not one thing for any individual; rather, each individual is both located in, and opts for a number of differing, and at times, conflictual, identities, depending on the social, political, economic and ideological aspects of their situation.

2. 'Shifting identities' in this chapter refers to the phenomenon of women expressing their preferred way of being as that of shifting between identities in order to evade 
violence. Assertiveness allowed in their career identity, for instance, causes conflict in their cultural identity. This leads them to 'becoming' submissive in their domestic roles in order to evade the violence of their partners.

3. Consequently, the main part of the chapter will consist of possible stories of women who shift (or do not shift) between identities to evade conflict especially vis-à-vis domestic violence. Each story's preferred outcome (to shift or not to shift) will be commented upon in terms of a possible alternative unique outcome, and the (un)healthiness of the choice for shifting between identities. At the end, short remarks will be made, opening up the question whether the practice of shifting between identities is a liberative survival choice or whether it enhances patriarchy. The stories newly constructed here are based on seven years of doing narrative counselling at a state hospital in Pretoria/Tshwane and described in Landman (2008), Township Spiritualities and Counselling.

4. Although a narrative approach to counselling is not evaluative, this chapter will explore the healthy and unhealthy impacts of shifting between identities on women in abusive situations by, firstly, considering outcomes in counselling alternative to shift between identities to evade violence, and secondly, by rescoping the discourses feeding women's choice to shift identities.

5. Narrative Therapy was founded by Michel White (Australia) and David Epston (New Zealand) with a publication in 1990, Narrative Means to Therapeutic Ends. During the past 20 years, Narrative Therapy has found a specific application in pastoral work in South Africa, and it is used by me both in counselling and in training ministry students in basic counselling skills (see 'Healing the Wounded', Landman 2020:1-6). In this article, I explain the theory and method of Narrative Therapy as follows:

Narrative Therapy takes social construction theory as its philosophical point of departure. Social construction theory simply states that, in the deep structure of reality, people are constructed by social discourses while, on the surface structure, these discourses are embodied in language. According to social construction theory, which depends heavily on the work of Michel Foucault, a discourse is a grand narrative that is upheld by society with a view to influencing human behaviour and mind sets. Healing may occur when, during therapy, harmful social discourses that obstruct healing are deconstructed in order to build healthy discourses that, in effect, nourish the telling of alternative stories.

When explaining Narrative Therapy to seminary or university students, and to an academic readership, I turn to an acronym, and teach Narrative Therapy as the MEET process. This stands for the main elements of Narrative Therapy: Mapping the past, Externalising the problem, Empowerment against the problem, and Thickening the alternative story. This acronym refers to an underlying principle of Narrative Therapy, that is, to create a dialogical space for counsellor and counselee to meet, and for binaries to enter into dialogue. (Landman 2020) 


\section{SHIFTING IDENTITY STORIES}

In popular media and from pulpits, people are encouraged to 'find themselves', that is, to know 'who I am' and to discover their true identity. However, in (narrative) counselling sessions, counselees often find more peace of mind when they acknowledge that they have different identities, e.g., a gender identity, a cultural identity, a working identity, etc.

Women, especially, often discover that their mental distress is due to the conflict between these identities, and that their gender, cultural and religious identities in particular are difficult to bring into line with one another. Many of these women then choose to shift between these identities in order to survive.

I myself often, when speaking publicly about violence and shifting identities, ironically use the example of the 'happy South African woman' who

- would be employed in a good job but one that does not threaten her husband yet brings in money for the household;

- would shift after hours to a cultural identity of submission in order to evade conflict at home;

- $\quad$ would tell the pastor she believes in the virgin birth; and

- would go to church on Sundays and believe in what is preached to her as her 'Biblical role' which is often in conflict with her human rights identity which she assumes during the week.

A happy woman in South Africa is one who skilfully shifts between identities. Or is she happy? Often in counselling, another story is told. To escape this circle of shifting identities is one of the most difficult to co-journey within counselling. It is like hunger. You cannot be counselled out of it. You cannot only change your mind and not feel the hunger anymore.

The following stories, as said, have been constructed by myself from a variety of stories to not refer to any woman specifically while illuminating the phenomenon of shifting identities. In constructing these probable stories to make them to present almost all women in South Africa, the following variables were taken into account:

- Age

- Race

- Marital status

- Economic standing

- Formal education

- Church 


\section{Susan (35), white, professional, mainline church}

Susan is an engineer who oversees a whole factory at work. She is an assertive and progressive leader, with whom the business is very satisfied. She is respected by a loyal staff of 50 highly trained people working under her. She is married to a professional man who occupies a position in middle management in the company for which he is working. They have three boys. However, her husband, for reasons she cannot discuss with him, submits her to excessive verbal abuse, humiliating her in public and private. She suspects it is because he feels threatened by her success, although he is successful himself. When they invite friends over, he makes fun of her food, and tells embarrassing intimate stories about her. When they do shopping, he would make a big scene indicating that she cannot drive a trolley and excessively apologises to people she has presumably bumped into with the trolley. He has installed extra safety measures in her car - although she as engineer knows they are useless - to safeguard his sons against her driving, thereby also preventing her from replacing her 12-year-old car. This encourages the three boys to behave as disrespectfully to her as their father.

Susan decides to deal with the situation by conforming more to the ideal of what she thinks a man finds attractive in a woman. She has been to a dietician to help her lose weight, and she has grown her hair, although this is not conducive to her working environment. She excels in being submissive and accommodating in her private life. By never saying something that may sound learned, by not giving an opinion, and by always applauding what her husband says and does, she has not convinced him to change his abusive behaviour, but she is keeping the family together and evades physical abuse which has occurred once before. Or so she thought, only to find out that her submissiveness irritates her husband even further, and her shifting identities opens her up to even further verbal and emotional abuse.

During counselling, Susan could find no other way of dealing with her husband's abuse than being quiet and accepting his abuse, finding fulfilment in her work. She consoles herself by the thought that this is what God wants, and what God will eventually reward. Alternatives to this forced preferred way of being are explored continuously. Susan has externalised the problem as 'humiliation with benefits'. Benefits are to remain part of a family which is of high importance to her, and not having to admit failure in marriage. She has identified the discourses that keep her captured in her situation which, inter alia, are: "Success in marriage means self-sacrifice for a woman", "God hates divorce", and "Divorce means failure".

After facing these discourses, she has tried once to stand up for herself at home, thereby acquiring a severe blow to her stomach, threats of a coming divorce, and a nervous breakdown which took her away from work for three weeks. It also earned her a note in her personnel file that she is unstable, which in turn costed her a promotion to top management. Susan therefore once more settles for shifting between a career 
identity that she needs to protect and an identity of submissiveness and the endurance of humiliation at home, accepting that she cannot escape the power of her husband.

\section{Puleng (28), black, secretary, mainline church}

Puleng (Tshwana) and Petros (Swazi) are deeply involved in their local church. They fell in love while working together in the church council. Petros negotiates lobola (bride prize) with her uncles. They are allowed to marry while Petros is still paying down the money. He struggles to do so, since he is 60 years old, and living off a state pension. Apart from a scarcity of money, the huge difference in age proofs to be one of the main problems in their relationship. However, they primarily disagree in their views of what a woman is. Puleng comes from a 'human rights generation', while Petros expects from her to wear the blanket of the makoti (bride), even when she goes to work and spend her spare time cooking and cleaning. Refusing to accept a submissive and controlled private identity, Puleng leaves Petros.

She informs him by sms that he should have himself tested for HIV. He goes after her and beats her. This is totally out of character for Petros. He has never before beaten a woman. Puleng gets a restriction order against him. Petros then approaches the pastor and insists that the church force her to return to him because that is what the Bible says. Also, now that she has infected him, she must look after him. The rift between Puleng and Petros is tearing the congregation in two, with the women taking sides with Puleng, and the men standing with Petros.

The pastor and Puleng's parents then visit Puleng. They insist that she goes back to Petros because it is God's will for women, and because the lobola is still being paid and the parents cannot afford to pay back to Petros what has already been paid. The pastor threatens to exclude her from the church community, and her parents from the family. Puleng returns and is now pregnant. She had no say in getting pregnant. She also fears the HIV status of the baby. She comes for counselling secretly, and has externalised the problem as "many rights, but nowhere to go". She identifies the discourses holding her captive as: "A good woman stays with her husband", "The government has given you human rights, but do not tell your husband", "The ancestors will punish a woman who killed a child who belongs to the clan through abortion", and others.

Having tried to run away once, Puleng lives within her religious and cultural identities, while dreaming of escaping into a human rights identity. Petros then dies of AIDS related illnesses, and his family, blaming her for his death, takes away the child from her. She is now working again, supporting herself, and growing in health with very little traces of HIV in her blood after taking her medicine regularly. She is lonely and 'marked' as HIV positive by friends and church alike. Once again, she is trapped in an identity that leaves her private and religious identities underdeveloped. She shifts to her career identity to escape the abuse and loneliness of her sexual and belief identities. 


\section{Mpho (44), black, worker, independent church}

Mpho works as a packer at the supermarket and is a very committed member of an independent church. Her mother is a sangoma (traditional healer) and Mpho is convinced that her mother is trying to steal the Holy Spirit from her in order to use the Spirit to do magic. Mpho fears that her mother will catch her in a Matrix. Furthermore, Mpho's sister gets dreams that a snake is coming from her vagina. Mpho convinces her sister to consult with the pastor of her church who is a healer, that is, a Christian one. Mpho's pastor baptises her sister in the river and drives the evil spirits from her. Then the dreams stop.

Also, Mpho's brother rapes her 14-year-old daughter, apparently regularly. Mpho's pastor then says that the daughter is to blame because she wears tight-fitting clothes, and that if the daughter continues to wear revealing clothes, Mpho must punish her according to Proverbs 22:15, using "the rod”. Mpho then beats her daughter - twice so badly with a sjambok (a heavy, traditional whip) that the school threatens to report it to the police if it would happen again. Sent for counselling, Mpho insists on talking only to a counsellor that is a "committed" Christian. Mpho externalises her problem as "The devil".

She is not willing to identify any human discourses as influencing her thinking. She only acknowledges her religious identity and wishes to accommodate all her other identities and knowledge in subordination under her religious identity. In short, Mpho only has a religious identity. Within this identity she internalises abusive religious commands and commits violence against others. Or rather, she escapes from her other identities to a religious identity where she commits violence, and in which she experiences trauma, fear, and confusion which she is not allowed to address.

\section{Tina (50), white, single, charismatic church}

At 50, Tina's life is still controlled by her 70-year-old mother who lives according to the ideals of a woman as ordained by God to be a housewife. Over the years, Tina's mother has become mean and controlling, driving her children away from her, blaming her husband for her unfulfilled life and humiliating him at home and whenever she accompanied him to professional functions. Tina's mother, according to Tina, is conflicted in herself, being bossy and controlling towards her husband and children, yet openly singing the praises of cultural and religious discourses that restrict women to unfulfilled lives. Tina secretly studied to become an accountant - although her mother took away her books when she found them, telling Tina that she was a failure because she could not get a husband. Using cultural arguments, the mother refused to let Tina leave the house.

At a rather advanced age, Tina manages to secure a good and well-paid job. She leaves home. Her mother, seeing that she cannot keep Tina home anymore, tries to control the process by buying Tina furniture that is to the mother's liking and not to 
hers. Tina deals with the situation by not revealing to her mother anything about her professional life. However, Tina struggles at work because of a lack of interpersonal professional skills, skills she never learnt from her mother who was caught up in the "small world of a self-restricted housewife", to use Tina's own words.

The identity of failure her mother has instilled in her for being unmarried, never leaves Tina. This identity of failure is enhanced by the charismatic church to which she belongs, who makes little religious space for single people and even "forces" them to attend "singles evenings" where they are matched. Since not finding a match at one of these meetings, Tina's feeling of failure as a woman grows daily. In counselling, Tina externalises her problem as "Identity of failure". She identifies as the discourses that keeps her captive: "A child should be grateful to her parents and respect them, no matter what", "An unmarried woman is a total failure", "People are not to be enjoyed and trusted, because they too will pull you in and keep you captive", and so on. Captured in an identity of failure as a single person, Tina shifts to her professional identity to escape the hurt and abuse which she has suffered as a child until she was 50. She is still feeling too unsafe to break out of her identity of failure to start healthy relationships with people, especially with men.

\section{Gina (55), white, single mother, professional, ecumenical officer}

Gina is a university-trained woman working at the gender desk of a large ecumenical organisation. This means that she is heading that department of her organisation that deals with gender-related issues and provides programmes that empower women against abuse. Gina is a single mother to a son, now 25, after her husband died in a motor car accident. Not having finished school, the son drifts from job to job. He drinks heavily and Gina suspects that he is on drugs, although she cannot discuss it with him at all. He refuses to leave the house and look for his own accommodation. He rules her and the house. If things are not cleaned up behind him, or his mother baths before him in the morning, leaving him with less hot water, he gets extremely angry. He only eats take-aways from expensive restaurants. He controls her whole life.

When she comes home from work, she must watch his television programmes with him. She may not watch the news or any programme with blacks in them. If she does not do what she is told, he breaks things in the house or keep her from sleeping. Constantly verbally abusing her, he enjoys humiliating her in public. He has taken on the role of the abusive husband, and there seems to be nothing she can do about it. When she goes away for work, he does things that forces her to come back, such as assaulting the neighbours. He has forced her to let the domestic worker go with whom Gina had a good relationship for many years. Gina must now do all the washing and cleaning herself.

Gina comes for counselling to tell somebody about her pain, something she cannot do in her working context. She has chosen to deal with the situation by shifting identities between her working context, where she works as a gender agent, and her home 
context, where she is constantly humiliated and controlled by her child. The only way to survive, she says, is simply to do as he says. Gina has identified quite a few discourses that holds her captive in the abusive relationship with her son, such as: "A good mother does not chase her child away", "A mother should be subservient to the men in the house", "A good woman does not speak out of the house", and "God punishes women who put their work before their family".

However, she says, it does not help her to know the discourses capturing her, because she cannot do anything about them. Whenever she asks her son to leave the house, he would get extremely angry and start shouting indecencies at her where everybody can hear. He has also threatened to set the house on fire if ever she would mention him leaving the house again. Gina is considering selling the house secretly and let the new owners deal with her son - but she fears the consequences. Therefore, she says, she will continue to empower women at work against abuse, but suffer it herself at home.

\section{Nonky (29), black, professional, "bekeerkerk”}

Nonky found out that her husband was cheating on her. When she confronted him, he wanted a divorce. Although she is a professional woman, she resigned from her job to stay at home, cooking and caring for him full time. She also used other covered power techniques to keep the relationship going, such as trying to get pregnant and reminding her husband of God's word that divorce is sin. Prioritising her identity as wife over that of her working identity, she nevertheless lost the relationship. After he beat her several times, her family came and removed her from the house to safety. Nonky went back to her husband several times, suffering more and more abuse. Eventually her family placed her under severe pressure to divorce, and after years they in fact got divorced.

Nonky cannot find another job. She went to the pastor of the "bekeerkerk" ("conversion church") as she calls it, for consolement, but he said that she had to take the blame for the situation since she was not submissive to her husband from the onset. Nonky was admitted to the hospital after a suicide attempt. She went back to her ex-husband's house where he lives with his new wife and set herself on fire. Fortunately, she was wearing protective clothing and she only suffered minor burns. She later got a job to run the till at a sports shop, which was unfulfilling as she was university trained. During counselling, Nonky externalises the problem as "Loneliness". She unwillingly identifies the discourses that keep her captive in a gender identity of failure.

They are discourses such as: "The wife is to be blamed when the husband cheats on her", "A happy couple is one where the wife makes the husband happy", and "God has not meant us to be single". Nonky has trapped herself in an abusive gender identity and refuses to shift to an identity where gender is not everything and not even the most important aspect of one's life. She still choses to go to her "bekeerkerk" and to confide in the pastor who enhances her failed gender identity as a divorced woman. 


\section{Anne (50), Brown, pastor in a mainline church}

Anne was born to very religious parents in a time when a girl's tertiary education was not deemed important and, actually, detrimental to her future life as a married woman. However, Anne persisted in studying. She first became a teacher and when her church started ordaining women, she studied to eventually become the first woman pastor in her church. She met her husband at university who was also studying to become a pastor. They got married and were called to two adjacent congregations. While her husband was welcomed overwhelmingly in his congregation, her congregants did not want to accept her, and the congregation was torn in two. But Anne persisted. She built up the congregation again and furthered her postgraduate studies to become the most knowledgeable person on the Church Order in her church. For these skills she was elected first to the leadership of the Regional Synod and then to the leadership of the General Synod. She was also appointed to a prominent academic post at the university.

Anne soon found out that nowadays, churches, like all organisations, are under pressure to elect women to their leadership. However, when a woman is elected to a leadership position, that woman takes the position of a man who thinks that this should have been his position. This has also happened in her case. Anne also quickly found out that men will not take her side against another man, because a man taking a woman's side will be known as a "friend of women".

After being elected to the General Synod Executive, the highest decision-making body in the church, Anne found herself in the firing line of one of the leaders of the Regional Synod who canvassed to be elected to that position. The level of harassment and victimisation is almost indescribable. After extensive slander campaigns, threats to those who do not support him, and compensation for those who do, he was not able to have her removed from her position. Actually, she has been elected to two further leadership positions, which really made him angry. In utmost acts of "unchurchorderly" behaviour, he tried to destroy the structures - that is the church itself - to which she has been chosen in a leadership position, creating chaos in dividing the church - still without being disciplined by the church. He would even go so far as to make court cases against her, telling lies and making slanderous remarks in the affidavits about her - and then withdrawing the cases before they can be tested in court, using the money of the Regional Synod for this. Affidavits handed in at court become accessible to the public. Therefore, Anne being both a church leader and an academic, was violated in both her religious and academic identities. During this time, Anne also lost her ever supportive husband to cancer, preventing her from escaping into a safe private space at home.

Anne comes for counselling simply because she has no one else to talk to. She escapes from the abusive environment somebody has created for her on different levels of the 
church structures, into an identity of loneliness and isolation. She tries, but there is no way in which she can address and fight the violence against her in her religious identity unless being marked as "the difficult woman", and the question being asked whether women should be elected into leadership positions in the church at all.

Anne externalises the problem as "Patriarchy in the church" and isolates a number of discourses that disempower her in positions of power in the church, such as: "A woman must remain feminine in leadership and please all", "Women should be grateful that the church ordains them", and "Women are by nature hysterical when they do not get what they want". In the meantime, Anne proceeds in her leadership roles, always feeling guilty that she is not pleasing enough, and always fearing that she will be removed from her position(s). She assumes a leadership identity of failure and fear, confused about what makes a woman "successful" in church leadership.

\section{Nomsa (26), black, recently unemployed, independent church}

Nomsa came for counselling after her mother, a professional nurse of high standing, bit her. Nomsa is an outward-going young woman. However, she has been fired from work because she was "insubordinate" and has as yet not received the compensation awarded to her by the Commission of Conciliation, Mediation and Arbitration (CCMA). Nomsa is very religious and belongs to an independent church. In this capacity she has performed some rituals in her mother's house, where she stays, to cleanse the house and especially the kitchen with all its utensils. Her mother, who belongs to a mainline church, is horrified by these rituals, and has forbidden Nomsa to enter the kitchen and especially, to cook. Because of this, a fight broke out between her and her mother, during which her mother bit her quite badly and chased her out of the house. Nomsa now lives at the back in a shack with the chickens.

Every Sunday, Nomsa goes to her church dressed in grey clothes with a little grey hat, and every Sunday the pastor drives the devil of insubordination out of Nomsa, although, he says, he fears that he will never be able to do that successfully with her "having too much of a man's mind". In counselling Nomsa is reluctant to externalise the problem, rather internalising it, finding the problem in herself as being insubordinate. She finds no other preferred way of being than to be subordinate within all her identities, at work (if she ever would find a job again), in house (if ever she was allowed back), and in church (if the pastor does not kick her out). There is no chance of her shifting between identities because she experiences violence and abuse in all of them. However, she has shifted to a predominantly religious identity, not experiencing the pastor's actions as abusive but as caring. 


\section{CONCLUDING EVALUATIVE REMARKS ON THE HEALTHINESS OF SHIFTING IDENTITIES}

Can it be healthy for women to shift between identities? Are the women whose stories have been told here really shifting between their different identities - or are they contextualising cleverly, surviving while living in different worlds?

In the above, we have encountered stories of women who are forced to shift between career identities where they can be assertive, and domestic identities where they are forced to be submissive or face violence. They are the engineer Susan who has chosen to be submissive to her husband, the gender agent Gina to her son, and the academic Anne to the patriarchal church leadership of her colleagues. They are choosing to shift between identities believing this is their only choice.

We have also encountered the stories of women who are forced to remain trapped in abusive cultural identities, while dreaming of a human rights identity (Puleng), or who shift to an equally abusive religious identity which they do not experience as abusive (Mpho and Nomsa). We have also told stories of women who remain trapped in an identity of failure (Tina). Although the women claim that shifting - or remain trapped - is the best choice to make for the sake of their mental and especially their physical health, one may ask if this is indeed the healthy option.

The healthy option, of course, would be not to shift between identities, but to shift one's identities in which you experience violence, to a safe place: Susan to a private identity in which she experiences partnership; Puleng to a human rights identity where she experiences inclusivity with friends; Mpho to a religious identity where her humanity is enhanced; Tina to an identity of fulfilled friendships instead of failure; Gina to an identity of mutual respect between her and her son; Nonky to a healthy gender identity; Anne to a leadership identity in which she receives acknowledgement; and Nomsa to an identity in which she can be spontaneous and outspoken without fear of dismissal and rejection.

In short, the women storied here should be in a position not to shift between identities, but to shift identity towards alternative forms of solidarity. However, as Annie Gagiano (2004:2) from Stellenbosch University warns us: It is not easy, in fact, it is dangerous, to subsume forms of solidarity alternative to the master-narrative. The stories of the women told in the above testify to this. And women will not be free to shift their identities to healthy spaces before a contra-culture has been established in society in which women can live in mental and physical safety. 


\section{REFERENCES}

Bhavnani, K. \& Phoenix, A. 1994. Editorial Introduction: Shifting Identities Shifting Racisms. Feminism E Psychology, 4(1):5-18. https://doi.org/10.1177/0959353594041001

Gagiano, A. 2004. Adapting the National Imaginary: Shifting identities in Three Post-1994 South African Novels. Journal of Southern African Studies, 30940:2-15. https://doi.org/10.1080/03057070420 00313031
Landman, C. 2020. Healing the Wounded: The Psalms and Therapy. Old Testament Essays, 33(3):1-6. https://doi.org/10.17159/2312-3 621/2020/v33n3a17

Landman, C. 2008. Township Spiritualities and Counselling. Research Institute for Theology and Religion: Pretoria.

White, M. \& Epston, D. 1990. Narrative Means to Therapeutic Ends. W.W. Norton: New York. 